\title{
ANALISIS PERBEDAAN VERBA AMARU DAN NOKORU
}

\author{
Oleh: \\ Elizabeth I.HA.N.R *) \\ Prodi S1 Sastra Jepang Fakultas Ilmu Budaya Universitas Diponegoro \\ Jl. Prof. Soedharto, S.H., Tembalang Semarang
}

\begin{abstract}
Japanese has specific vocabulary. Unlike Indonesian language that has more general vocabulary. When translated into Indonesian, there are several Japanese word that have the same or synonymous meaning. There are some words that can be selected to show a situation in Japanese. Amaru and nokoru is this type of word in Japanese. Amaru and nokoru have a same meaning if it translated in Indonesian. Which is 'sisa'. So in this study will be discussed more about the characteristics of these verbs.
\end{abstract}

Key word : amaru, nokoru, synonymous, sisa,

\section{PENDAHULUAN}

Semantik merupakan cabang ilmu linguistik yang mempelajari makna dalam suatu bahasa. Salah satu bidang semantik yang menarik untuk dibahas dalam pembelajaran bahasa adalah relasi makna.

Tidak sedikit kata dalam bahasa Jepang yang memiliki kesamaan makna antara satu yang lainnya, relasi makna seperti ini disebut dengan sinoim.

Sinonim merupakan bentuk bahasa yang maknanya mirip atau sama dengan bentuk lainnya; kesamaan ini berlaku bagi kata, kelompok kata, atau kalimat (Kridalaksana, 1984 : 154). Menurut Abdul Chaer dalam "Lingustik Umum" (1994 : 298) relasi sinonimi bersifat dua arah, namun makna dua ujaran yang bersinonim tidak akan persis sama karena faktor waktu, tempat atau wilayah, keformalan, sosial, bidang kegiatan, dan nuansa makna.

Verba (amaru 余る) dan (nokoru 残

る) sama-sama menunjukkan makna 'sisa' dalam bahasa Indonesia. Hal ini sedikit menyulitkan pembelajar bahasa Jepang untuk menggunakannya dalam kalimat dengan benar. Oleh karena itu pada penelitian ini akan dibahas persamaan dan perbedaan verba (amaru余る) dan (nokoru
残 る ) untuk memperjelas karakteristik masing-masing verba terebut.

\section{METODE PENELITIAN}

Metode yang digunakan pada penelitian ini adalah studi pustaka, yaitu studi dengan melalui buku-buku dan bahan lain yang relevan tanpa melalui langkahlangkah pengujian di lapangan. Dan penyajian hasil analisis data dilakukan dengan metode informal yaitu perumusan dengan menggunakan kata-kata biasa.

\section{HASIL DAN PEMBAHASAN \\ 3.1 Verba Amaru}

Verba (amaru 余る) menyatakan suatu bagian yang berada di luar jumlah yang diperlukan (ditetapkan) sebagai batas maksimal.

Sejalan dengan hal itu, Koizumi menyatakan bahwa verba (amaru 余る) mengandung makna (suuryou ga oosugite tsukawarezuni ato ni nokoru. 数量が多す ぎて使われずに後に残る (1993: 25), yang artinya 'karena jumlah terlalu banyak tidak terpakai, maka bersisa'. Seperti terlihat pada contoh berikut ini, 
1）材料が余らないようによく考えて買 う。(Kokuritsu Kokugo Kenkyuujo, 1988:22)

Zairyou ga amaranaiyouni yoku kangaete kau.

'Supaya bahannya tidak bersisa, berpikirlah baik-baik sebelum membeli.'

2)この会社は人が余っている。

(Kokuritsu Kokugo Kenkyuujo,1988 : 22)

Kono kaisha wa hito ga amatte iru.

'Perusahaan ini, orangnya bersisa.'

3) ジュースが 5 本余った。

(Koizumi, 1993 : 25)

Juuzu ga 5 hon amatta.

'Juice bersisa 5 botol.'

Kalimat 1) menyatakan agar kuantitas bahan dibeli tidak melebihi keperluan, disarankan untuk berpikir masak-masak sebelumnya. Kalimat 2) menyatakan jumlah orang yang bekerja di perusahaan ini melebihi jumlah yang diperlukan setelah ditempatkan pada pos-pos kerja yang ada, sehingga terjadi kelebihan pegawai. Kalimat 3) menyatakan jumlah juice yang bersisa ada 5 botol.

Selain itu verba (amaru 余る) digunakan dalam pembagian matematika yang tidak habis dibagi, seperti yang dinyatakan oleh Koizumi (warizan de) warikirezuni nokori ga deru (割り算で) 割 り切れずに残りが出る。) (1993：25).

Seperti pada kalimat berikut ini.

4) (*)15を 2 で割ると 7 が立って 1 残 る。 (Shibata, 1976:288)

15 o 2 de waru to 7 ga tatte 1 nokoru. 15 を 2 で割ると 7 が立って 1 余る。 15 o 2 de waru to 7 ga tatte 1 amaru. '15 dibagi 2 sama dengan 7 sisa 1.'

Pada kalimat 4) di atas, verba (amaru 余る) tepat dipergunakan karena menyatakan adanya sisa 1 dari pembagian 15 dengan 2 .
Selain itu verba amaru mengandung makna (aru hito no nouryoku no teido o koete iru ある人の能力の程度を越えて いる) (Koizumi, 1993 : 25), yang artinya melebihi derajat kemampuan seseorang. Verba amaru dengan makna ini digunakan dalam situasi formal (dengan makna kiasan). Seperti contoh berikut ini,

5)この問題はわれわれの力に余る。 (Kokuritsu Kokugo Kenkyuujo, 1988: 22)

Kono mondai wa wareware no chikara ni amaru.

'Masalah ini melebihi kemampuan kita.'

6) 最近の政治家の值落ぶりは目に余る。 (Kokuritsu Kokugo Kenkyuujo, 1988 : 22)

Saikin no seijika no darakuburi wa $\underline{\text { me }}$ ni amaru.

'Politisi akhir-akhir ini lebih banyak yang melakukan korupsi.'

7) 身に余る光栄。

(www.theasaurus.weblio.jp)

Mi ni amaru kouei.

'Kehormatan yang berlebihan.'

8)自分の手に余る難しい問題。 (www.theasaurus.weblio.jp)

Jibun no te ni amaru muzukashii mondai.

'Masalah yang sangat berlebihan untuk saya.'

Pada kalimat 5), 6), 7), dan 8) verba amaru menyatakan makna kiasan 'lebih', lebih dari kemampuan (chikara ni amaru 力に余 る) pada kalimat 5), lebih banyak (adanya) secara mencolok (me ni amaru目に余る) pada kalimat 6), berlebihan (mi ni amaru 身 に余る) pada kalimat 7), berlebihan (te $n i$ amaru手に余る) pada kalimat 8). 
Bila digambarkan, maka verba amaru mempunyai makna seperti terlihat pada gambar berikut ini,

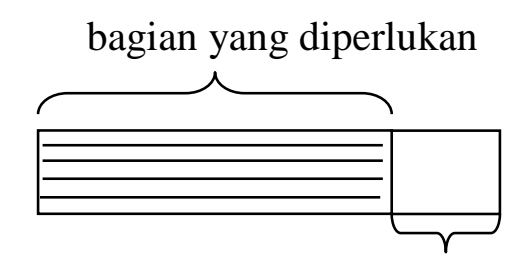

kelebihan

\section{Gambar 1. Makna Dasar Verba} Amaru

Verba amaru dapat dipadankan dengan kata 'sisa', 'bersisa', 'lebih', 'kelebihan' atau 'berlebih': masih ada sisa karena melebihi jumlah yang diperlukan dalam bahasa Indonesia. Menurut Kamus Besar Bahasa Indonesia disebutkan bahwa 'sisa berarti apa yang tertinggal', 'bersisa berarti ada sisanya (sesudah dimakan, diambil, dan sebagainya)', 'lebih berarti lewat dari semestinya; bersisa, ada sisanya; dalam perbandingan menyatakan sangat; kira-kira sekian bertambah sedikit; bertambah semakin', 'kelebihan berarti lebihnya, sisanya; keadaan yang melebihi yang biasa; keunggulan', 'berlebih berarti ada lebihnya; bersisa; terlampau banyak'.

Dari contoh-contoh di atas dapat dipahami bahwa yang menjadi titik berat sudut pandang verba (amaru 余る) adalah sesuatu yang melebihi kuantitas maksimal yang diperlukan (ditetapkan). Padanannya dalam bahasa Indonesia adalah kata 'sisa', 'bersisa', 'lebih', 'kelebihan' atau 'berlebih'.

\subsection{Verba Nokoru}

Shibata menjelaskan bahwa verba (nokoru 残る) dipakai untuk menyatakan suatu bagian yang menetap, terus ada dan berlanjut (tertinggal) (x) sebagai akibat dari perubahan waktu atau keadaan. Sebagai akibat perubahan tersebut, terjadi pengurangan (penyusutan) dari suatu bagian utuh X menjadi x (lihat gambar di bawah).
Sejalan dengan definisi di atas, dijelaskan bahwa verba (nokoru 残る) menyatakan (zenbu nakunaranaide mada $a r u$ 全部なくならないで、まだある) (Bunkachou, 1990 : 795), yang artinya tidak semuanya habis, melainkan masih ada. Seperti contoh kalimat berikut ini,

9)「それじゃ.......女たしの月給、三 万七千ですもの。アパート代と食費 に三万五千

使うから二千円しか、手許に残ら ないわ」 (Shibata, 1976:283)

"Soreja....., atashi no gekkyuu, sanman nanasen desu mono. Apaatodai to shokuhi ni sanman go sen tsukau kara ni sen en shika, te moto ni nokoranai wa."

"Kalau begitu.... karena gaji bulanan saya hanya 37.000. Setelah dipakai untuk menyewa apartemen dan biaya makan, yang tersisa di tangan hanya 2.000 yen saja."

10)長かった夏休みも 3 日しか残ってい ない。 (Kokuritsu Kokugo Kenkyuujo, 1988: 846)

Nagakatta natsu yasumi mo mikka shika nokotte inai.

'Liburan musim panas yang panjang pun, hanya tersisa 3 hari saja.'

Pada kalimat 9) dan 10) verba nokoru digunakan untuk menyatakan bahwa seiring dengan situasi dan berjalannya waktu, bagian utuh gaji bulanan (gekkyuu 月給) dan liburan musim panas yang panjang (nagakatta natsu yasumi 長かった 夏休み), mengalami penyusutan menjadi tinggal 2000 yen dan 3 hari saja. (Pada kalimat 9) dan 10) ini nokoru sepadan dengan 'tersisa' atau 'tinggal' dalam bahasa Indonesia ) 
Selain itu, verba (nokoru 残 る) digunakan juga untuk menyatakan hal berikut, (monogoto no aru joutai ga kienaide sono mama tsuzuku 物事のある 状態が消えないでそのまま続く) (Koizumi, 1993 : 400), yang artinya bahwa keadaan dari sesuatu tidak hilang (lenyap), namun berlanjut terus seperti kondisi sebelumnya. Seperti pada contoh kalimat berikut ini,

\section{1)傷あとが残る。}

Kizu ato ga nokoru.

(Shibata, $1976: 285$ )

'Bekas lukanya tersisa.'

12)彼女の顔には母親の面影が残ってい る。

(Koizumi, 1993 : 400)

Kanojo no kao ni wa haha oya no omokage ga nokotte iru.

'Pada wajahnya tertinggal bayangan (wajah) ibunya.'

Pada kalimat 11) dan 12) menunjukkan bahwa verba nokoru menyatakan makna seiring dengan berjalannya waktu 11) bekas luka, 12) bayangan (wajah) ibunya tidak hilang melainkan menetap / tidak hilang / membekas padanya untuk seterusnya.

Bagian utuh (X) yang mengalami pengurangan (penyusutan) tersebut, tidak hanya berupa sesuatu yang bersifat fisik saja, tetapi dapat juga berupa sesuatu yang bersifat abstrak seperti bau, atmosfir, ingatan, kenangan, perasaan, dan lain-lain. Seperti pada kalimat berikut ini,

13) その人が出て行ったあとに香水のに おいが残った。

(Kokuritsu Kokugo Kenkyuujo, 1988 : 846)

Sono hito ga dete itta ato ni kousui no nioi ga nokotta.

'Setelah orang itu pergi ke luar, wangi parfumnya masih tertinggal.'
14)この町には昔の城下町の雰囲気が残 っている。

(Koizumi, 1993 : 400)

Kono machi ni wa mukashi no Jougamachi no funiki ga nokotte iru.

'Di kota ini tertinggal atmosfer kota Jougamachi jaman dahulu.'

Hal tersebut didefinisikan oleh Koizumi dalam definisi verba nokoru (残る) berikut ini, (nanika ni taishite, aru kanjou ga kienaide, sono mama tsuzuku 何かに対し て、ある感情が消えないで、そのまま 続く) (Koizumi, 1993 : 400), yang artinya terhadap sesuatu hal, suatu perasaan itu tidak hilang, melainkan menetap begitu saja. Makna verba nokoru tersebut terlihat pada beberapa contoh kalimat berikut ini.

15）「女を誘惑するのが易しいがその女 を捨てるのはむつかしい。」僕はそ の頃誰かの本でそんな言葉を読んだ ことがある。それを書いた小説家の 名前はすぐに忘れてしまったが、こ の言葉だけは妙に頭に残っていた。 （『ユーモア小説 II』p . 156）

(Shibata, 1976 : 284)

"Kanojo o yuuwaku suru no ga yasashii ga sono onna o suteru no wa muzukashii." Boku wa sono koro dareka no hon de sonna kotoba o yonda koto ga aru. Sore o kaita shousetsuka no namae wa suguni wasurete shimattaga, kono kotoba dake wa myouni atama ni nokotte ita.

" Merayu wanita itu hal yang mudah, tetapi membuangnya adalah hal yang sulit." Pada waktu itu saya pernah membaca kata-kata itu di buku seseorang. nama pengarang novel itu segera terlupa, tapi anehnya kata-kata itu saja masih tertinggal di kepala.' 
16)彼らは負けた試合に悔いが残った。

(Koizumi, 1993 : 400)

Karera wa maketa shiai ni kui ga nokotta.

'Kekalahan mereka pada pertandingan menyisakan kekecewaan.'

\section{7) 不満が残る。}

Fuman ga nokoru.

(Koizumi, 1993 : 400)

'Terdapat ketidakpuasan yang tersisa.'

18)別れた彼女に未練が残る。

(Koizumi, 1993 : 400)

Wakareta kanojo ni miren ga nokoru.

'Tersisa hubungan batin dengan kekasih yang telah putus.'

Bau parfum (kouzui no nioi 香水のにおい) pada kalimat 13), atmosfir Jougamachi (jougamachi no funiki 城下町の雾囲気) pada kalimat 14), kata-kata ini (kono kotoba この言葉) pada kalimat 15), kekecewaan (kui 悔い) pada kalimat 16), ketidakpuasan (fuman 不満) pada kalimat 17), dan keterikatan (miren 未練) pada kalimat 18) merupakan bagian yang tertinggal dan menetap seiring berjalannya waktu.

Bila verba nokoru digunakan bersama dengan keterangan tempat, maka yang dimaksud bahwa subyek tetap (berada) di tempat yang sama. (ato made sono basho $n i$ $i r u$ あまでその場所にいる) (Bunkachou, 1990 : 795), yang artinya sampai nanti akan berada di tempat itu. Seperti terlihat pada contoh kalimat berikut ini,

\section{9)僕はここに残る。}

( Shibata, 1976 : 285)

Boku wa koko ni nokoru.

'Saya tetap tinggal di sini.'
20) 夜おそくまで会社に残って働く。

(Bunkachou, 1990 : 795)

Yoru osoku made kaisha ni nokotte hataraku.

'Tetap tinggal di perusahaan sampai larut malam untuk bekerja.'

21)授業が終わってから図書館に残って、 一人で勉強する。

Jugyou ga owatte kara toshokan ni nokotte, hitoride benkyou suru.

'Setelah kuliah selesai, (saya) tetap tinggal di perpustakaan untuk belajar sendiri.'

Kalimat 19), 20) dan 21) menyatakan bahwa subyek akan tetap tinggal atau berada di tempat yang disebutkan di sini, di kantor, dan di perpustakaan.

Dari ulasan di atas dapat disimpulkan bahwa verba (nokoru 残る) mempunyai fokus pada berlalunya waktu (jikan no keika 時間の経過) yang mengakibatkan hasil penyusutan sebagai keadaan yang menetap (sonzoku 存続) dan berlanjut (berlangsung) hingga seterusnya. Hal tersebut dapat digambarkan sebagai berikut ini,

(bagian utuh)

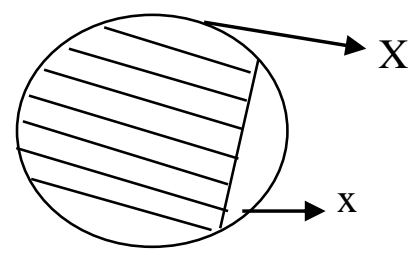

( bagian sisa yang menetap)

Dalam bahasa Indonesia makna verba nokoru ini dapat dipadankan dengan kata 'tersisa', 'tinggal': berada dalam keadaan semula tanpa dipergunakan atau dikurangi. Dalam Kamus Besar Bahasa Indonesia disebutkan bahwa 'sisa' adalah 'apa yang tertinggal'. (KBBI, 1996 : 949). Sementara 'tinggal' adalah $\mathbf{1}$ masih tetap di tempatnya; masih selalu ada (sedang yg lain sudah hilang, pergi, dan sebagainya); 2 sisanya 
ialah ...; bersisa ...; tersisa ...; yg masih ada hanyalah .... Berikutnya dalam bahasa Indonesia verba nokoru dipadankan juga dengan kata 'tertinggal' atau 'berbekas': berada dalam keadaan semula dan tidak hilang. Menurut Kamus Besar Bahasa Indonesia 'tertinggal' berarti ditinggalkan atau tercecer, dan 'berbekas' berarti ada (tampak) bekasnya; berkesan; memberikan kesan).

Dari contoh-contoh di atas dapat dipahami bahwa yang menjadi titik berat sudut pandang verba nokoru (残る) dalam bahasa Jepang adalah hasil penyusutan yang menetap, adanya perubahan waktu atau keadaan, dan proses. Padanannya dalam bahasa Indonesia adalah kata'sisa', ' 'tinggal', 'tertinggal', 'membekas'. Bila dilihat dari contoh-contoh yang ada selain yang bermakna aktif 'tinggal', situasi pada kalimat yang menggunakan verba (nokoru 残る) merupakan akibat yang terjadi secara otomatis sering dengan berjalannya waktu atau keadaan (tidak disengaja).

Bila merupakan tindakan yang terjadi atas keputusan manusia itu sendiri (aktif) maka verba amaru (余る) tidak bisa digunakan seperti pada kalimat 22) dan 23).

22)彼は図書館に残って勉強した。

(Shibata, $1976: 286$ )

Kare wa toshokan ni nokotte benkyoushita.

'Dia tetap tinggal di perpustakaan belajar.'

(*)彼は図書館に余って勉強した。

Kare wa toshokan ni amatte benkyoushita.

\section{3)お前はここに残れ！}

(Shibata, $1976: 286$ )

Omae wa koko ni nokore!

'Kamu tetap tinggal di sini!'

(*)お前はここに余れ!

Omae wa koko ni amare!
Pada kalimat 22) dan 23) di atas, verba (nokoru残る) lebih tepat digunakan karena mengandung makna 'orang yang tetap tinggal dan berada di tempat itu dengan kemauan sendiri, tanpa pergi dari tempat tersebut' (Kokuritsu Kokugo Kenkyuujo, 1988:846)

Pada kalimat berikut ini baik verba (nokoru残る) maupun (amaru 余る) dapat digunakan.

24)旅費が三千円残った。

(Shibata, $1976: 287$ )

Ryouhi ga sanzen en nokotta.

'Biaya wisata tinggal 3 ribu yen.'

旅費が三千円余った。

Ryouhi ga sanzen en amatta.

'Biaya wisata sisa 3.000 yen.'

25) 菓子がたくさん残った。

Kashi ga takusan nokotta.

(Waeijiten)

'Kue banyak tersisa.'

菓子がたくさん余った。

Kashi ga takusan amatta.

'Kue banyak banyak tersisa.'

26) ポットに残っていたらおかわりして もいいですか。

(Waejiten)

Potto ni nokotte itara okawari shite mo ii desuka.

'Kalau di teko masih tersisa, bolehkan saya tambah?'

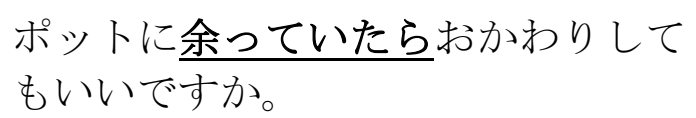

Potto ni amatte itara okawari shite mo ii desuka.

'Kalau di teko masih tersisa, bolehkah saya tambah?'

27) お金が残っていないようだ。

Okane ga nokotte inai youda. 
'Sepertinya uang tidak tersisa.'

お金が余っていないようだ。 Okane ga amatte inai youda.

'Sepertinya uang tidak tersisa.'

Pada kalimat 24) Seandainya uang yang dsediakan untuk wisata berjumlah 50.000 yen, maka pada kalimat yang menggunakan verba (nokoru 残る) dapat diinterpretasikan setelah dipergunakan untuk perjalanan wisata tersisa sebesar 3000 yen. Sementara untuk kalimat yang menggunakan verba (amaru 余る) dapat diinterpretasikan bahwa jumlah yang diperlukan sebagai biaya perjalanan wisata tersebut sebesar 47.000 yen, sehingga terdapat kelebihan uang sebesar 3000 yen. Dalam hal ini terlihat kesamaan makna antara verba (nokoru 残る) dan (amaru 余る) yaitu kuantitas, dimana verba (nokoru 残る) menyatakan kuantitas yang ada (aru ryou ある量) sedangkan verba (amaru 余る) menyatakan kuantitas yang lain (betsu no ryou 別の量). Uang yang ada sama-sama berjumlah 3000 yen, tetapi saat menggunakan verba nokoru, sudut pandang pembicara terletak pada bagian sisa yang merupakan sebuah hasil penyusutan yang menetap seiring berjalannya waktu atau proses, sementara sudut pandang pada saat mengguanakan verba amaru terletak pada bagian yang merupakan kelebihan dari yang diperlukan.

Pada contoh-contoh kalimat 23), 24), 25), 26), 27) di atas baik verba (nokoru残 る) maupun (amaru 余る) bisa saling bersubtitusi karena tidak mengandung makna aktif 'tinggal', obyeknya merupakan sesuatu yang kongkret, dan tidak disertai keterangan waktu yang menyiratkan adanya penyusutan akibat proses.

Pada kalimat 28) berikut ini verba (amaru 余る) tidak dapat dipergunakan karena tidak menyiratkan adanya proses berkurangnya kuantitas nasi seiring dengan berjalannya waktu dari 'tadi malam' hingga 'waktu ujaran' yang mana setelah itu kuantitas nasi tersebut menetap.

28)ゆうべのごはんがまだ残っている。

(Shibata, $1976: 288$ )

Yuube no gohan ga mada nokotte iru.

'Nasi tadi malam, masih sisa.'

(*)ゆうべのごはんがまだ余っている。 Yuube no gohan ga mada amatte iru.

\section{SIMPULAN}

Jadi, dapat disimpulkan bahwa persamaan verba (amaru 余る) dan (nokoru残る) adalah sebagai berikut,

1. Persamaannya,

1) Kedua verba tersebut menyatakan kuantitas.

2) Kedua verba tersebut merupakan verba intransitif dengan pola $(\sim g a$ nokoru / amaru〜 が 残る / 余 る.)

2. Perbedaannya,

1) Verba (amaru 余る) digunakan untuk menyatakan suatu bagian yang berada di luar kuantitas yang diperlukan sebagai batas maksimal. Dalam bentuk kiasan verba (amaru 余る) digunakan untuk menyatakan sesuatu yang melebihi batas. Sedangkan verba (nokoru 残る) digunakan untuk menyatakan adanya suatu bagian yang menetap, dan terus berlangsung sebagai akibat penyusutan yang terjadi seiring dengan perubahan waktu atau keadaan. Jadi dapat dikatakan bahwa fokus dari verba (nokoru 残 る) adalah suatu bagian yang terus ada (sonzoku 存続) setelah melewati proses (jikan no keika 時間の経過). Bila berhubungan dengan tempat, penggunaan verba (nokoru 残る) berarti berada di tempat yang sama sampai waktu tertentu. Verba (nokoru 残る) tidak bisa digunakan 
untuk hitungan matematika pembagian untuk menyatakan sisa.

2) Verba (amaru 余る) mempunyai obyek kongkret, sedangkan verba (nokoru 残る) mempunyai obyek abstrak dan kongkret

3) Verba (amaru 余る) tidak bisa digunakan untuk tindakan yang terjadi atas keputusan manusia itu sendiri (aktif).

4) Verba (amaru 余る) maupun (nokoru 残 る) bisa saling bersubtitusi, bila tidak ada keterangan waktu.

\section{DAFTAR PUSTAKA}

Aminuddin, Drs. 2008. Semantik Pengantar Studi Tentang Makna. Bandung. Sinar Baru Algensindo.

Bunkachou. 1990. Gaikokujin No Tame No Kihongo Yourei Jiten. Tokyo. Ookurashou.

Chaer, Abdul. 2007. Linguistik Umun. Jakarta. Rineka Cipta.

Koizumi, Tamotsu. 1993. Nihongo Kihon Doushi Youhou Jiten. Tokyo. Taishuukan Shoten.

Kokuritsu Kokugo Kenkyuujo. 1988. Kamus Pemakaian Bahasa Jepang Dasar. Tokyo. Unpublished
Robins, R.H. 1992. Linguistik Umum : Sebuah Pengantar. Yogyakarta. Kanisius

Shibata Takeshi. 1976. Kotoba No Imi 1. Tokyo. Heibonsha.

Tim Penyusun Kamus Pusat Pembinaan dan Pengembangan Bahasa. 1996. Kamus Besar Bahasa Indonesia. Jakarta. Balai Pustaka.

www.theasaurus.weblio.jp 